\title{
DISCONTINUITIES IN A TRANSVERSE VELOCITY PROFILE OF A VALLEY GLACIER MEASURED BY PHOTOGRAMMETRY
}

\author{
by \\ W. Kick \\ (Geographisches Institut, Universität Regensburg, D-84 Regensburg, Federal Republic of Germany)
}

\section{ABSTRACT}

The surface movement of part of a Nanga Parbat (Himalaya) glacier immediately below an ice fall has been investigated by terrestrial stereophotogrammetry. This method provides an opportunity of measuring many more points than by using other procedures. The shape of the transverse velocity profile indicated normal stream-like flow and not "blockschollen movement", as might have been expected, because of its high velocity $(45 \mathrm{~cm} / \mathrm{d})$. But, one feature of the ice fall above had been carried down-glacier to the location of the profile; namely, several discontinuities along the velocity diagram. The ice fall had transmitted a smal part of its splitting into seracs to the flatter area below, but not its blockschollen movement.

There seems to be a contradiction in that on one side there are discontinuities, i.e. the glacier is torn up into blocks by shear planes, but on the other side the glacier moves en bloc. In fact, a short-term investigation over hours or just a few days discloses cracks but, after time periods of a week or more, these irregularities compensate for one another so that they merge into a single unit block motion.

\section{MEASURING ICE VELOCITIES BY TERRESTRIAL PHOTOGRAMMETRY}

Terrestrial stereophotogrammetry offers special possibilities for the analysis of ice movement on glacier surfaces, mainly along transverse profiles. A greater number of points can be investigated by measuring on the photographs than by using stakes. One can employ this method in High Asia more of ten than, for example, in the Alps, because Asiatic glaciers are frequently covered by so much debris that a large number of surface points (stones) can be identified on two or more photographs taken within a time period of several days or weeks. The distances covered by these stones on their way down-glacier can be determined by a stereocomparator with high accuracy by "time parallax" or "motion parallax" (Finsterwalder, 1931; Konecny, 1964).

\section{BLOCKSCHOLLEN MOVEMENT}

It was on the occasion of the very first application of this method - by R. Finsterwalder in the north-west Pamirs in 1928 - that the so-called "blockschollen movement" (this name was given later) was described as a special movement type for fast-flowing glaciers. It is in opposition to the normal, regular stream-like flow of relatively slow-moving glaciers (in the following text described as flow and block movement).

In the case of block movement, a transverse velocity diagram has a characteristic shape: the velocity remains almost constant across the maximum central part of the glacier (up to $90 \%$ of the total width). There, the glacier as a whole moves as a single "block". Then, the speed decreases very rapidly towards both margins. This mode of movement therefore manifests itself as a trapezoidal velocity diagram, whereas in the case of normal flow movement the diagram has a parabolic shape, similar to that for viscous fluids.

In 1934, Finsterwalder (1938) found this same block movement in two Nanga Parbat valley glaciers with average velocities between 20 and $47 \mathrm{~cm} / \mathrm{d}$, as in 1954 did Pillewizer (1957) for several Karakorum glaciers with average velocities between 30 and $120 \mathrm{~cm} / \mathrm{d}$.

A second phenomenon is characteristic of fast-moving valley glaciers with block movement: beyond a certain upper limit of regular plastic deformation, the rapid movement causes friction. The surface is torn into numerous towers, crevasses, and blocks.

Because of these two features, this mode of movement is called "blockschollen movement" (Scholle = clod, lump).

\section{MOVEMENT EN BLOC AND "TORN INTO BLOCKS"}

In the first instance, the two features (moving en bloc and "torn into blocks") seem to contradict one another. Finsterwalder (1938) assumed relative motion between the blocks, but he could not determine it when evaluating measurements on the photographs, in spite of a very intensive and exact investigation. In not one case could he discern discontinuities in the velocity across the glacier. He deduced that the relative motion between the Schollen (lumps) must be rather small compared with the overall velocity of the block as a whole. Pillewizer wrote in letter to the author: "these discontinuities can be recognized only at short-term measurements (e.g. at periods of several hours or a few days)." Over longer periods of measurement (e.g. 1 or more weeks), they balance one another and disappear in the diagram which shows only the unit block motion.

Probably, the blockschollen movement is similar to that of certain catastrophic land slides. Their hurling masses are composed of single debris masses or rocks, but those lumps lose their individuality when they are canalized within a narrow valley. Each single rock is squeezed between neighbouring lumps. Thus, a unit summation of motion arises, which is a common motion of the whole mass.

\section{THE CHUNGPAR GLACIER PROFILE OF 1958}

In September 1958, a velocity cross-profile was measured by photogrammetry at the foot of an ice fall on Chungpar or Tarshing Glacier in the Nanga Parbat massif (north-west Himalaya). The location is $4.0 \mathrm{~km}$ above the terminus and $2.8 \mathrm{~km}$ below the firn line $(4550 \mathrm{~m})$. At the foot of the ice fall the surface slope changes from 20 to $11 \%$.

Evaluation of the photographs taken by phototheodolite resulted in a diagram of the longitudinal velocities $(\mathrm{cm} / \mathrm{d})$, deduced over a time period of $8 \mathrm{~d}$. The movement of 33 surface points on that transverse section gave an average over the whole glacier width of $45.3 \mathrm{~cm} / \mathrm{d}$, and a local maximum of $57.4 \mathrm{~cm} / \mathrm{d}$. In spite of this rather high velocity, which in other cases would be connected with block movement, the shape of the velocity diagram is parabolic, which is characteristic of flow movement. Also, 


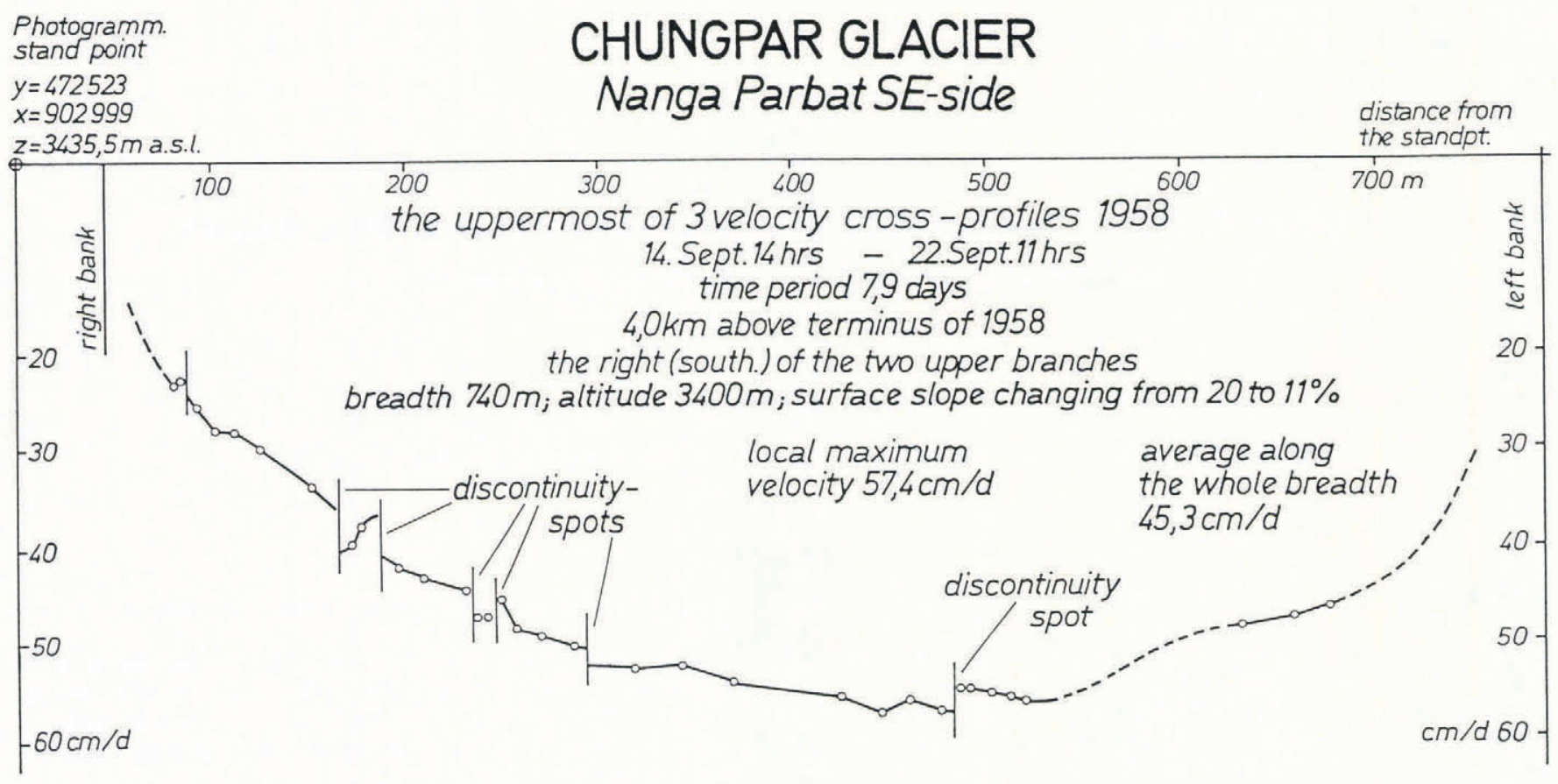

The measured profile has been transformed to a transverse perpendicular to the glacier

Fig. 1. Cross-profile of Chungpar Glacier, on the south-east side of Nanga Parbat.

the surface of the glacier does not show at all the roughness typical of block-moving glaciers. Within a rather short distance from the foot of the ice fall, the mode of glacier movement has changed from block movement, certainly active in the ice fall, into regular flow movement. But the discontinuities which must be expected between the seracs of the ice fall have been, at least partially, carried down to the location of the cross-profile. There, the generally continuous course of the velocity diagram is interrupted at least six times by leaps of $2-5 \mathrm{~cm} / \mathrm{d}$, or $3-12 \%$ of the velocity, with changes of sign (see Fig. 1). These discontinuities can be seen stereoscopically by using a stereocomparator. They can be interpreted as residuals of the feature of blockschollen movement which consists of shearing or breaking up into Schollen.

\section{WAVE OGIVES}

Another phenomenon occurs in the area of this profile which can be frequently encountered below ice falls, where the slope changes from a steeper into a flatter section, i.e. in a compression zone. Wave ogives emanate from the foot of the ice fall. Nye (1959) investigated the origin of such ogives at Austerdalsbre in Norway. He found no simple correlation between compression and wave formation but he stated that the waves were spaced at annual distances, namely from 240 to $75 \mathrm{~m}$ further down-glacier. The waves are fully accounted for by the combined plastic deformation (by compression in the lower parts of the ice fall) and the ablation mechanism. "All elements of ice are stretched out longitudinally as they pass down the icefall, owing to the

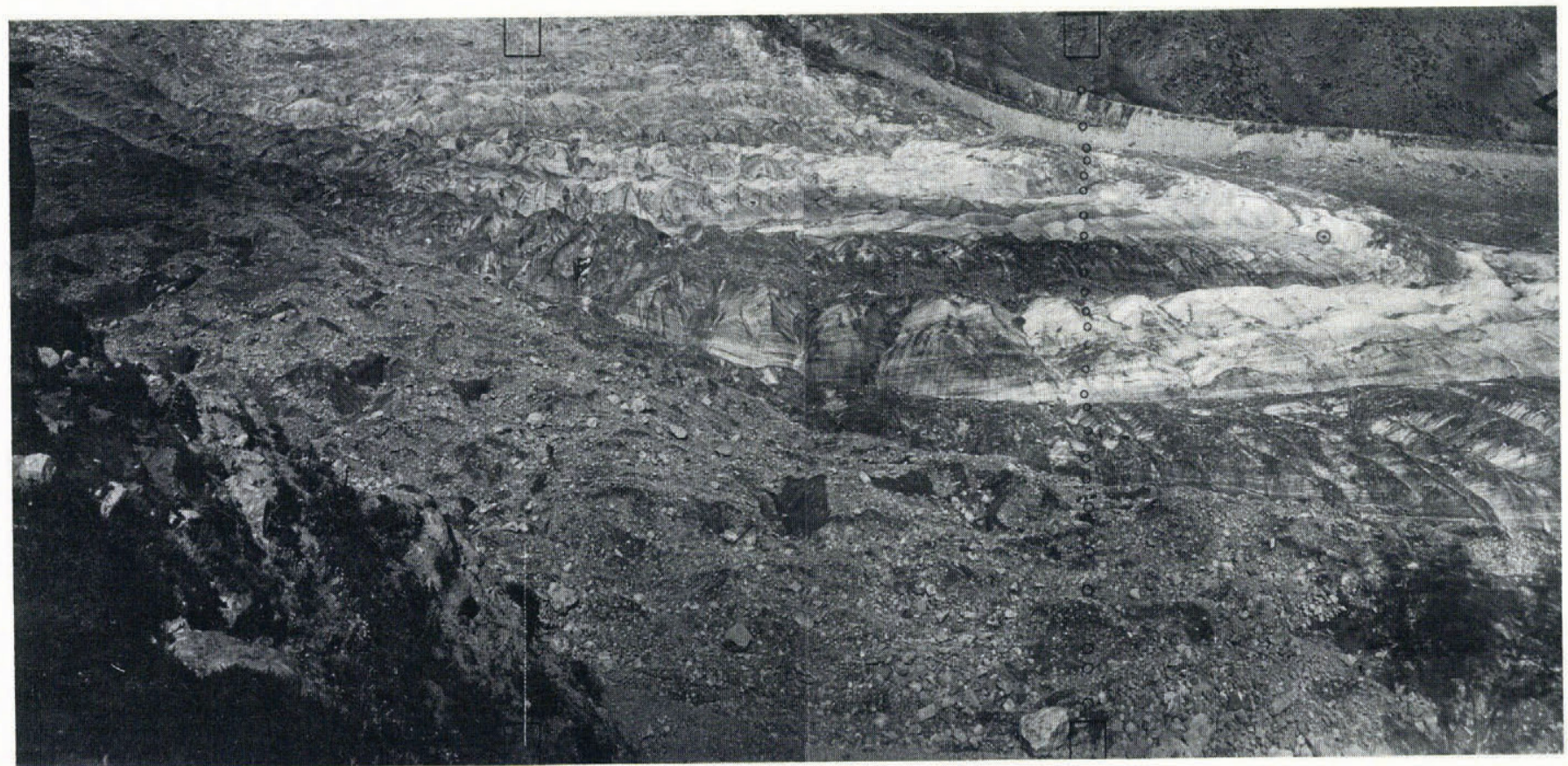

Fig. 2. Wave ogives below the ice fall on Chungpar Glacier, on the south-east side of Nanga Parbat, showing the site of the velocity cross-profile at $3400 \mathrm{~m}$ a.s.l. 
high local velocity, and they therefore present greater surface area. Those passing through the icefall in the summer therefore lose more ice by ablation ... . Waves are thus produced by the increased volume of ablation made possible by the plastic stretching in the icefall ...".

In the case of the Chungpar Glacier profile, the ice moved $3.6 \mathrm{~m}$ in $8 \mathrm{~d}$. It is, of course, incorrect to extrapolate from this temporary velocity to derive the annual movement. But this may provide the order of magnitude. We then get a figure of $165 \mathrm{~m}$ for the annual ice movement. The wavelengths have been measured in the photographs as being $73-109 \mathrm{~m}$. This result does not disprove the assertion that the waves correspond to the annual movement though, on the other hand, clear pressure structures may also exist below ice falls (Wilhelm, 1975, p. 143). The photographs (Fig. 2) show that the waves have already begun to form in the lowest parts of the ice fall and are fully developed at the foot of the ice fall.

\section{CONCLUDING REMARKS}

In September 1987, the same profile was measured again by photogrammetry, but the results are not yet available.* It may be of interest to note that, as early as 1856 , A. Schlagintweit made one of the first ice-velocity measurements in the whole of Asia on the very same Chungpar Glacier. He was the second explorer to investigate the movement of glaciers in High Asia, after R. Strachey had proved the existence of glaciers in the Himalaya by measuring the velocity of the ice on Pindari Glacier in 1848.

78 years after Schlagintweit, in 1934, Finsterwalder applied photogrammetry to Chungpar Glacier for the determination of velocities along a complete cross-profile. This procedure was repeated in 1958 by the author, who measured three transverse profiles across the same glacier. During that 24 year period, the glacier had lost $12 \mathrm{~m}$ in thickness at the location of the lower profile. But the temporary velocities (for time periods of $10 \mathrm{~d}$ ) had increased from 22 to $52 \mathrm{~cm} / \mathrm{d}$ (Kick, 1978). In September 1987, after a further quarter of a century, all three profiles were re-measured. This showed that the glacier surface had again shrunk enormously.

\section{REFERENCES}

Finsterwalder, R. 1931. Geschwindigkeitsmessung an Gletschern mittels Photogrammetrie. Z. Gletscherkd., 19, 251-262.

Finsterwalder, R. 1938. Die geodätischen, gletscherkundlichen und geographischen Ergebnisse der Deutschen HimalajaExpedition 1934 zum Nanga Parbat. Berlin.

Kick, W. 1978. Eisgeschwindigkeitsmessungen an Gletschern Hochasiens: Geschichte - Technik - Ergebnisse. Z. Gletchserkd. Glazialgeol., 13(1/2), 1977, 7-22.

Konecny, G. 1964. Glacial surveys in western Canada. Photogramm. Eng., 30(1), 64-82.

Nye, J.F. 1959. The deformation of a glacier below an ice fall. J. Glaciol., 3(25), 387-408.

Pillewizer, W. 1957. Bewegungsstudien an Karakorumgletschern. Petermanns Geogr. Mitt. Eigänzungsheft 262, 53-60.

Wilhelm, F. 1975. Schnee- und Gletscherkunde. Berlin and New York, Walter de Gruyter.
*First results. For a period of $8 \mathrm{~d}$ the velocities for the profile in question were on average $15 \%$ smaller than in September 1958. This is not surprising, since the ice thickness had decreased by an average of $15 \mathrm{~m}$ during the 29 years. 